\title{
Gender differences in time use among adolescents in developing countries: Implications of rising school enrollment rates
}

Amanda Ritchie

Cynthia B. Lloyd

Population Council

Monica J. Grant

Population Council

Follow this and additional works at: https://knowledgecommons.popcouncil.org/departments_sbsr-pgy

Part of the Demography, Population, and Ecology Commons, Educational Sociology Commons, Family, Life Course, and Society Commons, Gender Equity in Education Commons, and the International Public Health Commons How does access to this work benefit you? Let us know!

\section{Recommended Citation}

Ritchie, Amanda, Cynthia B. Lloyd, and Monica J. Grant. 2004. "Gender differences in time use among adolescents in developing countries: Implications of rising school enrollment rates," Policy Research Division Working Paper no. 193. New York: Population Council. Version of record: https://doi.org/ 10.1111/j.1532-7795.2008.00552.x 


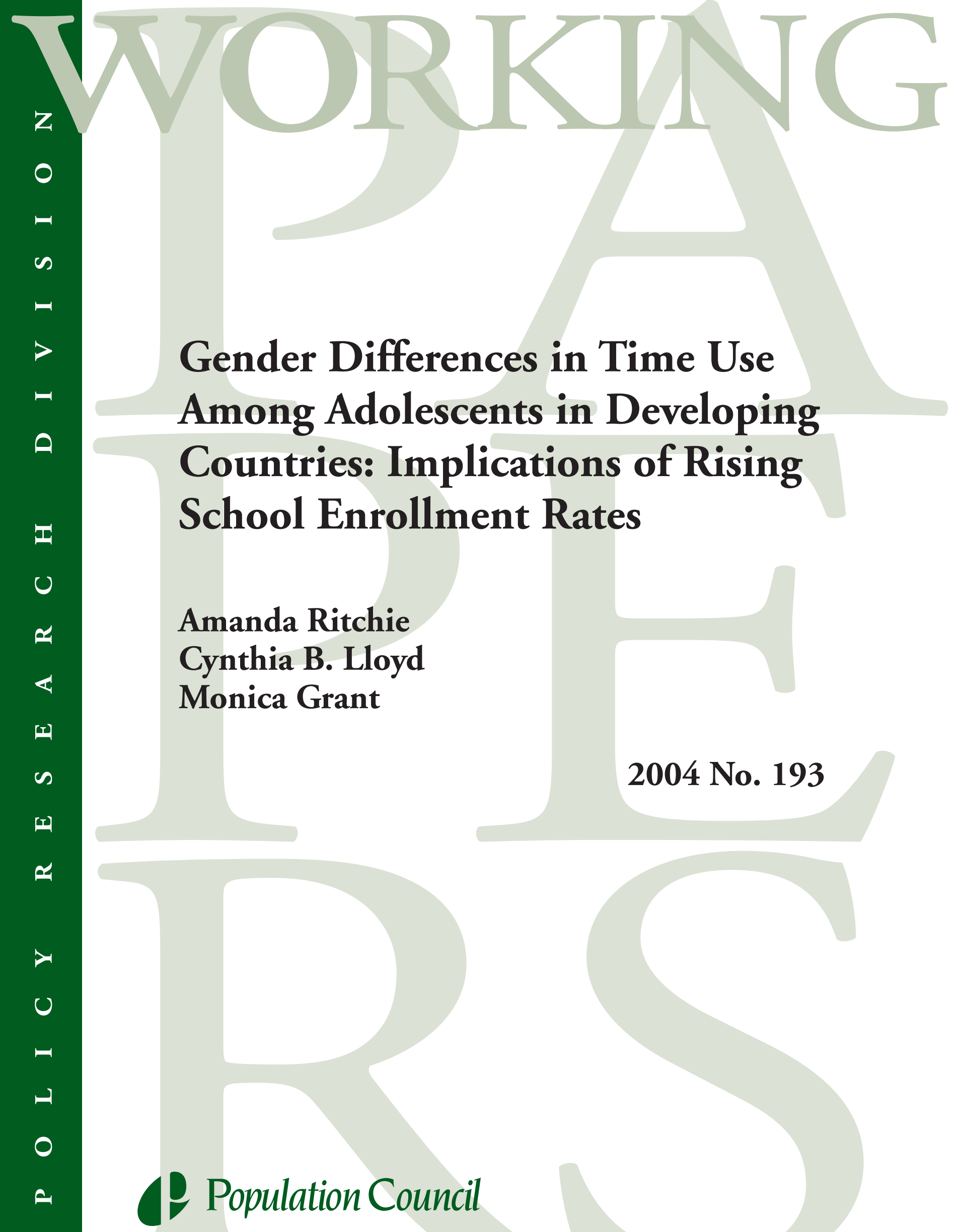




\title{
Gender Differences in Time Use Among Adolescents in Developing Countries: Implications of Rising School Enrollment Rates
}

\author{
Amanda Ritchie \\ Cynthia B. Lloyd \\ Monica Grant
}

\begin{abstract}
Amanda Ritchie is Project Coordinator and Ethnographer, Institute for AIDS Research, National Development and Research Institutes, New York. Cynthia B. Lloyd is Director, Social Science Research, and Monica Grant is Research Coordinator, Policy Research Division, Population Council.
\end{abstract}

Acknowledgments: The authors acknowledge collaborators on each of the surveys undertaken by the Population Council that were used in this analysis: India (Barbara Mensch, Mary Sebastian), Kenya (Ayo Ajayi, Wesley Clark, Annabel Erulkar, and Karin Hyde), Pakistan (Judith Diers, Azeema Faizunnissa, Mumraiz Khan, Zeba Sathar, Munawar Sultana, and Minhaj ul Haque), and South Africa (Lisanne Brown, Kelly Hallman, Carol Kaufman, Kate MacIntyre, Robert Magnani, and Naomi Rutenberg). The authors express their thanks for comments from Sarah Gromly and Joann Vanek. They also acknowledge the generous support of the United Kingdom Department for International Development. An earlier version of this paper was presented at the Population Association of America annual meeting in Boston, April 2004.

This material may not be reproduced without written permission from the authors. For a list of Policy Research Division Working Papers, including those that are currently available for downloading in PDF format, see www.popcouncil.org/publications/wp/prd/rdwplist.html.

(C) 2004 The Population Council, Inc. 


\begin{abstract}
Three research questions are addressed in this paper: (1) How does time use change during the transition to adulthood? (2) Does gender role differentiation intensify during the transition? (3) Does school attendance attenuate gender differences? Researchers at the Population Council have been involved in the collection of 24-hour recall data on time use from adolescents in India, Kenya, Pakistan, and South Africa. Sufficient data have now been collected to permit comparative analysis. These data are supplemented by comparable data from Guatemala and Nicaragua from the World Bank Living Standard Measurement surveys. Our research addresses significant gaps in the literature, in particular the lack of attention to how time use is affected by school attendance. The data document differences in time use patterns between students and nonstudents. Although female adolescent students still work longer hours than male adolescent students, the gender division of labor that typically develops during adolescence is greatly attenuated among students when time spent at work is measured by combining labor market work with noneconomic household work.
\end{abstract}


A dramatic growth has occurred in the school enrollment rates of adolescents in developing countries over the last 20 years (National Research Council 2005a). As a result, the mean age of school exit is rising, and the gender gap between boys and girls in school participation and grade level attained is narrowing rapidly. The increase in school participation and grade attainment worldwide has been accompanied by a decline in the labor force participation rates of the young, especially those of children and young adolescents (National Research Council 2005a). Thus, more and more boys and girls are spending longer periods of time into early or middle adolescence engaged in similar types of activities, with some of that time typically spent together in the same classroom. These changes in enrollment and labor force participation rates have implications for the differentiation in gender roles that takes place during adolescence. Because adolescence is the stage of the life cycle when gender role differentiation intensifies, it is also a period of increasing concern to researchers interested in the formation of gender roles and to policymakers committed to promoting gender equality and women's empowerment (e.g., United Nations Millennium Development Goal No. 3 on gender equity).

Surprisingly, however, most research on gender role differentiation has focused on adults. A recent comprehensive treatment of gender issues in developing countries (World Bank 2001) catalogues the many ways in which greater gender equality can contribute to development, but it does not explore the ways in which gender role differentiation develops during adolescence or the factors that contribute to shaping that process. The United Nations Millennium Project Task Force on Gender Equality is beginning to recognize that adolescents and young people should be target groups for policies designed to eliminate gender inequality (United Nations Millennium Project 2004).

The analysis of adolescent time use in key domains such as labor market work, noneconomic household work, school, and leisure can enrich our understanding of the circumstances in which young people experience the transition to adulthood. Comparative research that examines time use separately for different groups of adolescents (by gender, age, and school status) and in different developing countries has not been possible in the past because the necessary data were not easily available. In this paper, we explore and compare data on time use among adolescent students and nonstudents using recent and reasonably comparable data from a heterogeneous sample of developing countries. In particular, we focus on the implications of rising rates of school attendance for gender differences in time use.

The paper begins with a brief review of the literature, noting the scarcity of published data on time use among adolescents in developing countries that are differentiated by enrollment status. Next we introduce our data, summarizing some of their strengths and weaknesses. This is followed by a description of differences in enrollment patterns across the countries we have selected, so that our time use data can be interpreted within the proper context. The data analysis proceeds in two steps. First, time use patterns are described and compared according to enrollment status across countries. Then, results of Tobit regressions are summarized, focusing in particular on gender 
differences in the change in time use patterns associated with school enrollment, including noneconomic household work and leisure activities.

\section{REVIEW OF THE LITERATURE}

Mensch and her colleagues' (1998) comprehensive review of research and policy on adolescence in the developing world notes the lack of multidimensional research on the lives of adolescents. Most such research focuses on specific domains of their lives such as reproduction, education, work, and health, but rarely examines the context of adolescents' behaviors or the interrelationships among various domains. In recent years, interest has grown in the interrelationships between labor market work and schooling, but this interest rarely extends more broadly to encompass interrelationships among other domains of young people's lives.

All of the studies we reviewed presented detailed data on the allocation of working time, differentiating noneconomic household work from labor market work. Most explored the interrelationships between time spent working and at school, although data on the amount of time spent on school-related activities were rarely presented and probably not often collected. Only a few of the studies, primarily those based on time use data from 24-hour recall, provided information on time spent in all three of the major domains: work, school, and leisure. Even more rarely are data published concerning average amounts of time adolescents spend on different activities by sex and school enrollment status. ${ }^{1}$

From this review of the literature, we single out three major empirical findings that appear to apply universally. These findings will come as no surprise. The first is that significant differences are seen in the way boys and girls spend their work time, regardless of age; boys are more likely to work for pay or for their families' economic gain, and girls are more likely to perform noneconomic household work or domestic chores. $^{2} \quad$ Second, the total amount of time devoted to all work activities (labor market activities and noneconomic household activities combined) rises with age for both boys and girls. ${ }^{3}$ Thus, as boys and girls move through the transition to adulthood and assume more work responsibilities, the daily lives of boys become increasingly different from the daily lives of girls. Third, girls tend to spend longer hours than boys on all work activities combined, leaving boys more time for leisure activities. ${ }^{4}$

Larson and Verma's (1999) review of studies of time use among adolescents documents the widespread tendency for boys to have more leisure or "free" time than girls. They contend that boys typically spend less time on domestic work. Their review includes relatively few data from developing countries, however. In a study of time use in South Africa, Chobokoane and Budlender (2002) found that, although a slightly higher proportion of boys than girls engage in social and cultural leisure activities, among those who report leisure activities boys and girls spend about the same amount of time on them.

As a consequence of rising enrollments and an increasing proportion of adolescents participating in higher levels of schooling, the assumption is made that young people will have less time available for work. Logically, the types of work that students 
perform might be expected to differ from the types of work taken up by those who are not enrolled in school. In many countries, however, school days are short and school holidays and vacations are long. Therefore, combining work activities with school attendance is not always difficult. Indeed, estimates based on 15 UNICEF household surveys fielded in Africa in 1995 suggest that the proportion of enrolled students combining some work with schooling rises with age, reaching a majority of students by age 12 (Huebler and Loaiza 2002). ${ }^{5}$ This finding might suggest that, as young people leave school at later ages, students are increasingly likely to combine some work with schooling as they grow older. This tendency may, indeed, be seen in Mexico according to an analysis of trends in time use among Mexican young people from 1984 to 1992 - to our knowledge the only study in which trends in time use could be analyzed using comparable data (Abler et al. 1998). For both boys and girls in urban and rural areas, the authors found a decline in the proportion of adolescents (aged 12-18) who are categorized exclusively as students (rather than as students who also perform some labor market work). At the same time, they found a rise in school enrollment rates. As they advance in age, students are increasingly likely to take up some labor market work to support their continued school attendance (National Research Council 2005a).

Evidence of school/work tradeoffs comes from evaluations of several recent antipoverty programs promoting children's schooling among poor families in Bangladesh and Mexico, among other countries, with grants that are conditional on school attendance. In their analysis of the effects of the Food for Education program in Bangladesh, Ravallion and Wodon (2000) found that school subsidies lead to higher enrollment rates and lower labor market participation rates among program participants, but the decline in the proportion of those recorded as working was only one-fourth of the increase in enrollment. In their analysis of the effects of PROGRESA in rural Mexico, Skoufias and Parker (forthcoming) found that the decline in labor force participation rates for boys was on a par with the rise in school enrollment, except among older adolescents (aged 16-17). Adolescent female participants balanced school attendance against some declines in noneconomic household work. The results of these studies suggest that the relationship between various types of work and schooling is complex. Work and schooling do not just cancel each other out. Some young people combine the two, while some do neither.

These studies and others like them typically focus on changes in participation rates rather than on changes in the amounts of time spent on different activities - a problem that has been noted previously (see Levison and Moe 1998; Ilahi 2001). Because the nature of adolescents' activities is so variable between and within countries, comparing adolescents on the basis of their rates of participation in different activities can mask significant differences in how much time they spend on each activity.

Although a burgeoning literature exists on work and school interrelationships, the primary focus has been on labor market work and its implications for schooling. Much less attention has been paid to other aspects of work (in particular, noneconomic household work), ${ }^{6}$ to the total time devoted to schooling, and to the ways in which leisure time is used. Furthermore, few studies provide information on the typical length of the 
school day or the school year, which varies greatly across countries and is an important contextual factor explaining variations in adolescents' time use patterns.

Finally, differences in measurement techniques often compromise comparability of surveys within and across countries. Among the studies we reviewed, a few relied on direct observation, but most used either 24-hour or seven-day recall, occasionally supplemented by time logs. Some data sets relied on adults to report on the time use of adolescents, and some relied on direct reports from adolescents. Lloyd and Grant (2004) compared the results of two different reporting approaches in Pakistan and found substantial differences. In the 1991 Pakistan Integrated Household Survey (PIHS), women and girls were asked how many times in the past seven days they performed 12 different noneconomic household tasks and how much time they spent performing each activity. For the 2001-02 Adolescent and Youth Survey of Pakistan (AYSP), young people were asked to recall their activities in the previous 24-hour period in half-hour increments. The interviewer recorded the responses according to the appropriate categories. In the AYSP, all adolescent respondents answered questions about their activities directly; in the PIHS, only 53 percent of adolescent respondents answered questions about their activities (Durrant 2000 and 2003). ${ }^{7}$ In comparing these two data sources, the authors found that significantly greater time was reported for noneconomic household chores in the AYSP, which relied on 24-hour recall. Mean weekly hours for those reporting housework was given as 27.4 in the PIHS but as 43.5 in the AYSP (by converting daily hours to weekly hours) - a difference too great to plausibly represent trends in time devoted to household chores over the ten years elapsed between the two surveys. Instead, these differences suggest that seven-day recall leads to substantial underestimates of time devoted to particular activities.

\section{DATA AND CONTEXT}

Researchers at the Population Council have been involved in the collection of time use data from adolescents in developing countries as part of a major research initiative on transitions to adulthood. In each country where research has been undertaken, the survey of adolescents has included a time use module based on 24-hour recall in one-hour increments. The 24-hour recall approach was used rather than the lastseven-day approach because time use reported over a seven-day recall period leads to substantial underestimates of time spent on nonschool, unremunerated, or noneconomic activities. The collection of time use data among young people served two purposes: It sheds light on the activities of adolescents' everyday lives in developing countries, and it provides insights about the optimal timing of interventions for the young.

Sufficient data have now been collected to permit comparative analyses. These data include a sample from rural communities in three districts of Kenya (1996), a sample from largely urban households in Durban, South Africa (1999), a national sample of young people in Pakistan (2001-02), and a sample from urban slums in Allahabad, India (2003). These data can be supplemented with information from World Bank Living Standard Measurement surveys conducted in Guatemala and Nicaragua that employed a 
similar approach to the measurement of time use. Although respondents' age ranges vary from survey to survey, all surveys include most or all of the teenage years. Table 1 summarizes the key features of each of these data sets.

In the interest of comparing the time use of students to that of young people of the same age who are not attending school, special care was taken in the surveys undertaken by the Population Council to conduct them when schools were in session. ${ }^{8}$ Moreover, leisure time was not considered as a residual after school time and work time had been determined. Time spent sleeping, eating, traveling (sometimes), and on personal maintenance were not included as leisure time but were recorded separately.

In our descriptive analysis, we focus on the broad categories of time devoted to school, time devoted to all types of work, and time devoted to leisure. Work time is further divided into paid labor market work, unpaid economic work, and noneconomic household work, and is measured in reasonably comparable categories across the surveys. When we report average hours spent on each activity, we include data for those who did not participate in that activity. All data are presented separately by residence (urban or rural) and enrollment status (student or nonstudent).

Tables $2 \mathrm{a}$ and $2 \mathrm{~b}$ provide the wording printed in each questionnaire describing the activities to be included under each category: school, leisure, noneconomic household work, paid labor market work, and unpaid labor market work. The intention of each survey was to limit noneconomic household work to domestic chores such as housework, caring for family members, fetching fuel and water, raising food directly for the family, and home maintenance. ${ }^{9}$ Unpaid labor market work, by contrast, includes work for family profit or gain. Paid labor market activity includes work for pay whether the work takes place within or outside the household. The questionnaire wordings are not identical, so that minor differences may be found among the categories used for different countries. These differences are unlikely to affect our basic conclusions, however.

The six surveys included in this comparative analysis took two different approaches to the measurement of time use for those currently enrolled in school. In three of the surveys (India, Kenya, and Pakistan), the interviewers were instructed to ask currently enrolled students to report their time use on the most recent school day if the previous day was not a school day. Thus, for these three data sets, reported time use is confined to days when school was in session (typically weekdays), whereas the time use reports of those not currently in school could apply to any day of the week. ${ }^{10}$ Because the time use patterns of students differ between school days and nonschool days, this approach is likely to underestimate the amount of time students spend working and enjoying leisure activities relative to the time nonstudents spend on such activities over the course of a week. Nonetheless, the reports should be representative of the differences in time use between students and nonstudents that occur on a school day.

The other three surveys (Guatemala, Nicaragua, and South Africa) collected data for the previous 24 hours regardless of whether they fell on a school day or a nonschool day. Thus, for these three surveys, we can compare the time use of students and nonstudents over the whole week, and for two of the three (Nicaragua and South Africa) 
we can also compare time use on a school day as well, because information about the day or date of the interview was available.

Table 3 provides a comparison of these two approaches to the measurement of time use as illustrated by the data from the Nicaragua and South Africa surveys. For nonstudents, the two approaches present a similar picture. For students, however, leisure time and work time are substantially undercounted if we confine the measurement of time use only to days when school is in session. For example, the estimate of mean daily hours spent working (at economic and noneconomic work combined) is 2.5 hours for rural male students in Nicaragua if the measure is confined to a school day but 3.6 hours if the measure represents any day of the week. The same comparison for girls is 2.6 hours for a school day and 3.8 hours if nonschool days are included in the average. The differences in leisure time are even greater. As a result, differences between students and nonstudents in the amount of leisure time shrink substantially when school days and nonschool days are combined. Not surprisingly, students trade off hours in school for work time and leisure time over the course of the week, spending relatively more time on work and leisure on nonschool days than on school days. This tradeoff is less feasible, however, when school is in session for six rather than five days a week. In our sample of countries, schools in Pakistan are in session six days a week, and schools in India are in session five and a half days a week.

As background, we provide school participation rates for 15-19-year-olds by sex and residence (urban or rural) from each of the data sets in order to show that a substantial range in enrollment rates is represented in these surveys (see Figure 1). Among the urban samples, South Africa has the highest levels of school participation at this age for both boys and girls (about three-fourths), followed by Nicaragua, Guatemala, and India (more than 50 percent), with Pakistan at the bottom of the distribution with slightly more than a third. The greatest gender gaps in this sample of countries are in Pakistan ( 9 percentage points) and South Africa ( 7 percentage points). Among the rural samples, South Africa again has the highest levels of school participation (about threefourths), followed by Kenya with more than 50 percent. Enrollments at these ages in rural areas are extremely low in Guatemala, Nicaragua, and Pakistan, with sizable gender gaps in all countries but Nicaragua.

\section{DeSCRIPTIVe Data AnAlysis}

Figure 2 presents overall patterns of students' daily time use in school-related activities on a school day. ${ }^{11}$ To increase comparability across countries, we confine these comparisons to students aged 15-19, an age group common to all surveys. School-related activities include time spent in school and time spent studying. School-related time varies substantially from a little more than five hours in South Africa to roughly ten hours in rural Kenya. These variations are explained primarily by differences across countries in the length of the school day. Within each country, girls and boys spend about the same amount of time on school-related activities. Any small differences between boys and 
girls are due to gender differences in study time, which are trivial in most settings except in India, where boys appear to spend at least one more hour a day studying than girls do.

Next, we compare total time spent on all types of work including paid labor market work, unpaid labor market work, and noneconomic household work using two different reference periods - a school day or any day. Comparisons are possible for five countries for a school day-India, Kenya, Nicaragua, Pakistan, and South Africa, and for three countries for any day-Guatemala, Nicaragua, and South Africa (see Figure 3). Again, we confine our comparison to the 15-19 age group. In all cases, those who are not enrolled in school report substantially more work hours than do enrolled students regardless of the reference period. This finding is not surprising given that school takes up a significant portion of the day, as noted above. In almost all cases except rural Nicaragua for nonstudents, girls report more total work hours than boys do whether or not they are students. Among students, gender disparities in total work time are greatest for urban India, with girls reporting, on average, two more hours of work than boys on days when school is in session. Typically, gender differences in students' total work time on a school day are about an hour. Among adolescents who are not enrolled, gender differences in total work time typically are also about an hour, but are slightly more in rural Pakistan, urban Guatemala, and rural and urban South Africa. Thus, although school attendance reduces total work demands, female students still work longer hours than male students.

A final observation on the links between school participation and work comes from a comparison of Figures 2 and 3. South Africa has the shortest school day and Kenya the longest. Kenyan students appear to work for a shorter time on a school day than students in any of the other countries because they have less time available for work. Thus, differences in the length of the school day among countries may be one factor explaining variation in the extent to which work and schooling are combined. Our sample of countries is too small to pursue this relationship more fully.

When we explored the subcategories of work separately, we found that adolescents in all countries report little time on unpaid labor market work (less than an hour per day), except for those in rural Kenya. Therefore, we combined unpaid and paid labor market work into one measure and contrast that measure with time devoted to noneconomic household work.

In all cases, girls spend much more time than boys on noneconomic household work, and these differences become substantial among those who are not enrolled in school (see Figure 4). Among girls who are not enrolled, mean daily hours of noneconomic household work vary from roughly five to more than seven hours, whereas for boys in the same category the range is from about half an hour to three hours. Gender differences in noneconomic household work never exceed two hours, on average, among students but range from two to five hours among those who are not in school. Among nonenrolled adolescents, the most gender-equitable time use patterns in noneconomic household work are found in South Africa. Young men in urban Pakistan and urban India and in rural Kenya appear to spend little time performing domestic chores whether or not they are in school. Adolescent girls and boys in rural areas spend about an hour per day 
more than their urban counterparts performing domestic tasks, a finding contrary to results from Peru, where urban adolescents were reported performing more domestic work than rural adolescents (Ilahi 2001; Levison and Moe 1998).

A comparison of Figures 4 and 5 indicates that male students typically spend relatively more time on noneconomic household work than on labor market work. An assumption is often made that boys do not perform domestic household chores, but our findings show that boys who are enrolled contribute more to the household through noneconomic household work than through economic activity. This finding represents an additional factor that makes the daily lives of male and female students similar. Female students, however, still perform more noneconomic household work than male adolescents who are not enrolled in school.

Time spent by students on labor market work is rarely substantial. The main exception is in rural Guatemala, where male students appear to work more than three hours a day. Among nonenrolled male adolescents, the mean time devoted to labor market work on a school day varies enormously across countries in rural areas, from less than one hour in South Africa to seven hours in Kenya. The variation is smaller in urban areas and reflects variations in the ease of entry into the labor force in these economies. Only in Guatemala, Kenya, and urban Nicaragua does labor market work seem substantial among girls, whether or not they are enrolled.

Because of differences among countries in the measurement of leisure time, we focus primarily on differential patterns within countries rather than on differences across countries. In every comparison, on days when school is in session students clearly enjoy less leisure time than those who are not enrolled (see Figure 6). In almost every case except that of rural Kenya, male students enjoy more leisure time than female students. Gender differences in leisure are greatest in South Africa. This pattern is slightly less typical among nonstudents. Young women who are not enrolled in school enjoy roughly the same amount of leisure time as young men in urban Pakistan and India and in rural Kenya. In rural Nicaragua, young women who are not in school appear to enjoy slightly more leisure time than young men.

These patterns allow us to conclude fairly confidently that the sharp increases in school participation and grade attainment that have occurred around the world in the past 20 years can be linked with a decline in overall work burdens as well as a decline in labor force participation rates among adolescents. Because our data are relatively recent and because gender gaps in enrollment are closing rapidly, we can also conclude that the time use patterns of all adolescents, at least during the early and middle phases of the transition to adulthood, are becoming more similar than they have been in the past. Finally, in those countries where the school day is relatively long, the lives of female and male students become most similar to one another during the school week as enrollment rates continue to rise and gender gaps continue to close. 


\section{IMPLiCATIONS OF ENROLLMENT STATUS FOR TIME USE: GENDER DifFERENCES}

From the data provided here, it is difficult to determine whether being enrolled in school implies greater changes in time use for boys or for girls. To test for gender interactions in the relationship between enrollment status and time use, we use Tobit IV estimation techniques to regress daily hours devoted to work and leisure activities on age (using dummies for age groups), enrollment status, marital status, and age/enrollment interaction terms. ${ }^{12}$ This technique allows us to avoid the asymptotic bias of ordinary least squares regression that occurs when there is a reasonable percentage of zero observations. Our intention is not to develop a causal model. We are well aware that many of the same factors that determine enrollment status also determine time allocation. Instead, we use this approach to identify patterns in the relationship between enrollment status and time use by sex while controlling for the effects of age.

Tables 4 through 7 summarize our findings separately for each time use category (total work, noneconomic household work, labor market work, and leisure) in terms of the signs and statistical significance of the regression coefficient on enrollment status. The statistical significance of gender differences in the measured relationship is derived by pooling the separate male and female regressions and running gender-interaction terms on each of the right-hand-side variables. The direction and significance of gender differences are indicated in a separate column of each table.

Table 4 summarizes the results by country and reference period (school day or any day of the week) for the difference between students and nonstudents in daily hours devoted to all types of work (labor market work and noneconomic household work combined). With the sole exception of females in rural South Africa, school enrollment is significantly associated with a reduction in total work time. In every case but that of urban South Africa, however, when the reference period is any day of the week the difference in work time associated with enrollment is less for girls than for boys, and these gender differences are sometimes significant. The gender differences in effects are most highly significant in India and Pakistan, which are known to have strongly differentiated patterns of time use by sex. In such settings, school participation makes a particularly substantial contribution to equalizing work burdens according to sex.

Table 5 summarizes the results for time devoted to noneconomic housework. For girls, school enrollment is associated with less time devoted to noneconomic household work, and the relationship is always significant. For males this association is found in most cases (although it is less often significant). Some interesting exceptions are seen for urban Pakistan and urban and rural Guatemala, where boys' time devoted to noneconomic household work appears to be greater for students than for nonstudents. Everywhere except in rural South Africa, girls show greater differences than boys as a result of enrollment status in time spent on noneconomic household work, which is to be expected given that girls are starting from a much higher base. Furthermore, these gender differences are almost always highly significant.

Table 6 complements Table 5 by exploring differences associated with school enrollment in time devoted to labor market work. Because so few young people in South 
Africa actually participate in labor market work, we are not able to present findings in

this table for South Africa, because the results are unstable and implausible. ${ }^{13}$ The differences in market work for boys according to enrollment status are always significant and are occasionally significant for girls as well. In general, the patterns of gender differences are complementary to the pattern of gender differences found for noneconomic household work. Thus, school participation reduces gender differences in work patterns.

Table 7 presents differences in daily hours devoted to leisure activities according to enrollment status. Except in Guatemala, girls who are students have less leisure time than girls who are not enrolled, and the differences in leisure time by enrollment status are sometimes significant. For boys, the patterns across countries are divergent. In some cases, students appear to have more leisure time than nonstudents, whereas in other cases the reverse is true, particularly in rural areas. In most cases, the differences in leisure time between those who are enrolled and those who are not are greater for young women than for young men.

\section{Conclusions}

The main point of this paper is a simple one: The lives of adolescent boys and girls in developing countries are becoming more similar than they have been in the past as they spend more of their adolescent years in school. Our data clearly document differences in time use patterns between students and nonstudents across a diverse sample of countries. Although female adolescent students still work longer hours than male adolescent students, the gender division of labor that typically develops during adolescence is greatly attenuated among students when time spent at work is measured by combining labor market work with noneconomic household work. This change has occurred not only because male and female adolescent students spend much of their day together in school, but also because the distribution of their work time (compared with that of nonstudents) is similar.

In most cases, male students devote a majority of their work time to noneconomic household work whereas young men who are not in school devote the majority of their work time to labor market activities. Students also enjoy slightly less leisure time. In many cultural settings, boys and girls tend to spend their leisure time differently. The length of the school day and the number of days during the week that school is in session can also affect the distribution of time use among students.

Our data show that for girls (particularly girls not enrolled in school) and for male students, noneconomic household work takes up a considerable amount of their work time. Most policies and programs aimed at reducing child labor focus on paid and unpaid economic work as the primary deterrents to schooling. Our findings suggest that the effects of adolescents' noneconomic household work on school status and performance should be explored further and addressed in policies and programs that seek to improve and equalize educational attainment for all adolescents. 
For girls, extending schooling into their adolescent years can be seen as a first building block in a societal pathway toward establishing greater gender equality for adults, not only because of the learning that takes place in school but also because school brings adolescent boys and girls together in the same place to spend their time similarly during a critical phase of their transition to adulthood. Although female students still carry a slightly heavier workload and enjoy less leisure time than male students during their adolescent years, these gender differences are trivial compared with the gender differences in time use that are apparent among adolescents who do not attend school. 


\section{Notes}

1 Arends-Kuenning and Amin (2003) report on time use data collected in rural Bangladesh using open-ended 24-hour recall and provide comparisons by sex of time spent in agricultural work. Among those aged 11-19, male nonstudents perform about 2.5 hours more agricultural work per day than do male students (the time spent by male students on agricultural work varies from 1.5 to 2.5 hours a day, depending on the season). Girls typically spend no more than an hour a day on agricultural work; female nonstudents spend slightly more than female students on farm work. Data on time spent on domestic work are provided only for girls, and data on time spent on wage work are provided only for boys. Mason and Khandker (1998) report on two time use data sets from Tanzania and compare total work time for students and nonstudents, but their methodology for data collection (for example, identity of respondent, length of recall) is not discussed. They show heavier work burdens for girls at every age whether they be students or nonstudents, but lighter workloads for students than for nonstudents. In the most recent Uganda Demographic and Health Survey, parents were asked to report on their children's time spent working in the previous week. The average work hours are surprisingly similar for students and nonstudents. Mean hours spent on all work activities combined (domestic work, family farm or business, and paid work) averaged 19.2 hours per week for male students and 18.4 hours per week for male nonstudents (aged 6-17); 20.5 hours were reported for female students and 22.8 hours for females not in school (number of hours were derived from data provided in Uganda Bureau of Statistics and ORC Macro 2002).

${ }^{2}$ See recent literature reviews on time use, including Torun et al. (1994) and Larson and Verma (1999). Specific examples, including Jain's (1996) analysis of time use data from Rajasthan and West Bengal, India, show that girls aged 9-19 spend 1.7 to 4 hours per day more than boys of the same age on domestic work. A number of other studies confirm this finding (Cain 1977; Evenson et al. 1980; White 1975, as cited in Rodgers and Standing 1981; Levison 1993; Canagarajah and Coulombe 1998; Kramer 2002; and Skoufias and Parker 2002). In Peru, Ilahi (2001) finds that boys spend, on average, 3.7 hours per week on wage work, whereas girls spend 2.8 hours per week on paid work.

${ }^{3}$ Data from several early pioneering studies of time use clearly document the rise in work time with age during the adolescent years (see Cain 1977 for rural Bangladesh and Nag et al. 1978 for Java and Nepal). More recent data from Bolivia show that the average time spent in work activities begins at less than an hour for children aged 6 and rises to 6.9 hours for young people aged 18 (Psacharopoulos 1997).

${ }^{4}$ Levison et al. (2001), using 1996 data from urban Mexico, show that at every age from 12 to 17, girls spend more hours per week than boys in labor force work and household chores combined. Drawing on time use data from a diverse range of settings, Ersado (2002) documents girls' heavier workload in Nepal, Peru, and Zimbabwe. 
${ }^{5}$ Huebler and Loaiza (2002) defined young people as working if they reported either at least one hour of economic activity in the last week or more than four hours a day of domestic work.

${ }^{6}$ Several articles authored or coauthored by Levison (Levison 1993; Levison and Moe 1998; Levison et al. 2001) are notable exceptions.

${ }^{7}$ On average, the girls themselves reported spending more time on each activity than their surrogates reported (Durrant 2003).

${ }^{8} \mathrm{~A}$ few of the interviews conducted in Guatemala and Nicaragua may have taken place during school vacation time, however. This circumstance may explain why the work rates for students in these two countries, particularly in Guatemala, seem higher than those of the other countries.

${ }^{9}$ In Guatemala and Kenya, home construction, repair, and maintenance are included under unpaid labor market work, whereas in South Africa home construction, maintenance, and yardwork are included under noneconomic household work. According to United Nations guidelines (the UN Draft International Classification of Activities for Time-Use [ICATUS]), such activities as "do-it-yourself decoration, maintenance, and small repairs" and "cleaning and upkeep of dwelling and surroundings" should be listed under noneconomic household work. Because of the slight differences in wording of these questions and because these questions were not designed to ICATUS standards, it is not entirely clear whether they should be reclassified for our analysis. In any case, the levels of time reported for these variables are low; therefore, recategorizing these variables would not change the distribution of time use between categories in any meaningful way.

${ }^{10}$ Reports could apply to any day if interviews were conducted on every day of the week.

${ }^{11}$ Guatemala is not included in this comparison because we cannot determine from the available data whether or not time is reported on a school day.

${ }^{12}$ To be more precise, the variables in the regressions are dummies for the age groups $12-14,17-19$, and $20-21$, with ages $15-16$ as the reference category; enrollment status (student $=1$ ); marital status (married $=1$ ); and interaction terms for each age group with enrollment status. The age variable $17-19$ is common to all surveys. The age group 1214 , however, is available only for Guatemala, Kenya, and Nicaragua, and the age group $20-21$ is available for all countries except Kenya.

${ }^{13}$ In South Africa, less than 7 percent of boys and 5 percent of girls report spending any time on labor market work in the past 24 hours (or school day). In all other surveys, the overall proportion reporting spending any time on labor market work exceeds 40 percent for boys and 15 percent for girls. 
Table 1 Summary of time use data sets, by selected variables, according to country and survey date

\begin{tabular}{|c|c|c|c|c|c|c|}
\hline Variable & $\begin{array}{c}\text { Guatemala } \\
(2000) \\
\end{array}$ & $\begin{array}{l}\text { India } \\
\text { (2003) } \\
\end{array}$ & $\begin{array}{l}\text { Kenya } \\
\text { (1996) } \\
\end{array}$ & $\begin{array}{c}\text { Nicaragua } \\
\text { (1998) } \\
\end{array}$ & $\begin{array}{l}\text { Pakistan } \\
(2001-02) \\
\end{array}$ & $\begin{array}{l}\text { South } \\
\text { Africa } \\
\text { (1999) } \\
\end{array}$ \\
\hline $\begin{array}{l}\text { Total sample size } \\
\text { Urban } \\
\text { Rural } \\
\text { Student } \\
\text { Nonstudent }\end{array}$ & $\begin{array}{c}16,045 \\
6,648 \\
9,397 \\
8,061 \\
7,984\end{array}$ & $\begin{array}{c}6,148 \\
6,148 \\
\text { na } \\
2,717 \\
3,431\end{array}$ & $\begin{array}{c}774 \\
\text { na } \\
774 \\
589 \\
185\end{array}$ & $\begin{array}{l}5,115 \\
2,605 \\
2,510 \\
2,765 \\
2,350\end{array}$ & $\begin{array}{l}8,062 \\
3,327 \\
4,735 \\
1,358 \\
6,704\end{array}$ & $\begin{array}{r}3,051 \\
2,385 \\
666 \\
2,198 \\
853\end{array}$ \\
\hline Coverage & National & $\begin{array}{c}\text { Urban } \\
\text { slums in } \\
\text { Allahabad }\end{array}$ & $\begin{array}{l}\text { Kilifi, } \\
\text { Nakuru, } \\
\text { and Nyeri } \\
\text { provinces }\end{array}$ & National & National & $\begin{array}{l}\text { KwaZulu- } \\
\text { Natal } \\
\text { province }\end{array}$ \\
\hline Age range (years) & $7-25$ & $15-21$ & $12-19$ & $7-25$ & $15-24$ & $14-22$ \\
\hline Period of recall & $\begin{array}{l}\text { 24-hour } \\
\text { recall }\end{array}$ & $\begin{array}{l}\text { 24-hour } \\
\text { recall (or } \\
\text { previous } \\
\text { school day) }\end{array}$ & $\begin{array}{l}\text { 24-hour } \\
\text { recall (or } \\
\text { previous } \\
\text { school day) }\end{array}$ & $\begin{array}{l}\text { 24-hour } \\
\text { recall }\end{array}$ & $\begin{array}{l}\text { 24-hour } \\
\text { recall (or } \\
\text { previous } \\
\text { school day) }\end{array}$ & $\begin{array}{l}\text { 24-hour } \\
\text { recall }\end{array}$ \\
\hline $\begin{array}{l}\text { Data collection } \\
\text { method }\end{array}$ & & & -Interview w & h adolescents & & \\
\hline $\begin{array}{l}\text { Units of time } \\
\text { reported }\end{array}$ & $\begin{array}{l}\text { Hours and } \\
\text { minutes }\end{array}$ & $\begin{array}{c}\text { 1-hour } \\
\text { increments }\end{array}$ & $\begin{array}{c}\text { 1-hour } \\
\text { increments }\end{array}$ & $\begin{array}{l}\text { Hours and } \\
\text { minutes }\end{array}$ & $\begin{array}{c}\text { 1-hour } \\
\text { increments }\end{array}$ & $\begin{array}{c}\text { 1-hour } \\
\text { increments }\end{array}$ \\
\hline
\end{tabular}

na $=$ Not available. 
Table 2a Activities specified in survey, by country, according to time use categories

\begin{tabular}{|c|c|c|}
\hline Country & School & Leisure \\
\hline Guatemala & $\begin{array}{l}\text { Attend school, carry out any other } \\
\text { type of studies, do homework, and/ } \\
\text { or go to the place where you study }\end{array}$ & $\begin{array}{l}\text { Participating in any sporting } \\
\text { activities, cultural activities, and/or } \\
\text { relaxation (playing, watching } \\
\text { television, going to movies, theater, } \\
\text { etc.) } \\
\text { Providing any free service or } \\
\text { participating in community work or } \\
\text { meetings }\end{array}$ \\
\hline India & $\begin{array}{l}\text { In school } \\
\text { Homework }\end{array}$ & $\begin{array}{l}\text { Visiting with friends inside household } \\
\text { Visiting with friends outside } \\
\text { household } \\
\text { Visiting adolescent resource center } \\
\text { Participating in games/sports } \\
\text { Watching television/movies } \\
\text { Playing/listening to music } \\
\text { Reading magazines/stories } \\
\text { Other recreation }\end{array}$ \\
\hline Kenya & $\begin{array}{l}\text { In school } \\
\text { Homework }\end{array}$ & $\begin{array}{l}\text { Social and recreational (includes } \\
\text { playing, attending family gatherings, } \\
\text { gossiping, religious activities, going } \\
\text { to parties and meetings, watching } \\
\text { television and listening to radio) }\end{array}$ \\
\hline Nicaragua & $\begin{array}{l}\text { School/university/other training } \\
\text { Homework }\end{array}$ & $\begin{array}{l}\text { Resting (napping), recreation, } \\
\text { reading, talking with someone, } \\
\text { watching television, snacking } \\
\text { Going to social meetings (weddings, } \\
\text { birthdays, funerals, etc.) or visiting } \\
\text { friends or relatives } \\
\text { Participating in community services } \\
\text { (parish activities) }\end{array}$ \\
\hline Pakistan & $\begin{array}{l}\text { In school } \\
\text { Homework/tuition/studies at home }\end{array}$ & $\begin{array}{l}\text { Visiting friends/relatives } \\
\text { Watching television/movies } \\
\text { Reading magazines/listening to music }\end{array}$ \\
\hline South Africa & $\begin{array}{l}\text { In school/university/technical } \\
\text { school } \\
\text { Study leave and homework }\end{array}$ & $\begin{array}{l}\text { Socializing at home } \\
\text { Going to mall/shopping center/street } \\
\text { corner/ "hanging out" } \\
\text { Watching television, listening to } \\
\text { music, reading, talking on phone } \\
\text { Participating in sports/games } \\
\text { Attending sports events, concerts } \\
\text { Going to parties, shebeen (bar), club } \\
\text { Attending club or group activities/ } \\
\text { participating in community service }\end{array}$ \\
\hline
\end{tabular}


Table 2b Activities specified in survey, by country, according to time use categories

\begin{tabular}{|c|c|c|c|}
\hline Country & Noneconomic household work & $\begin{array}{l}\text { Paid labor market } \\
\text { work }\end{array}$ & $\begin{array}{l}\text { Unpaid labor } \\
\text { market work }\end{array}$ \\
\hline Guatemala & $\begin{array}{l}\text { Cleaning house } \\
\text { Cooking or preparing meals } \\
\text { Washing dishes } \\
\text { Washing or ironing clothing } \\
\text { Throwing out trash } \\
\text { Hauling water } \\
\text { Collecting firewood } \\
\text { Serving and/or looking after children }\end{array}$ & $\begin{array}{l}\text { Paid work at company } \\
\text { or institution, farm or } \\
\text { garden plot (in cash or } \\
\text { in-kind) } \\
\text { Paid work in own } \\
\text { business, farm, or } \\
\text { garden plot as an } \\
\text { independent worker } \\
\text { (in cash, benefits, or } \\
\text { in-kind) }\end{array}$ & $\begin{array}{l}\text { Helping in the } \\
\text { activities of the family } \\
\text { farm, garden plot, or } \\
\text { household business, or } \\
\text { for other persons } \\
\text { Weaving, } \\
\text { embroidering, making } \\
\text { or processing articles } \\
\text { of clothing for } \\
\text { household members } \\
\text { Caring for animals } \\
\text { Making repairs to own } \\
\text { dwelling of any type: } \\
\text { electrical, plumbing, } \\
\text { bricklaying, etc. }\end{array}$ \\
\hline India & $\begin{array}{l}\text { Inside house (dishwashing, cleaning, } \\
\text { cooking, mending, etc.) } \\
\text { Outside house (raising food or livestock } \\
\text { for family use, fetching water, etc.) } \\
\text { Caring for children, sick, and elderly }\end{array}$ & Paid work & $\begin{array}{l}\text { Unpaid work } \\
\text { (excluding chores and } \\
\text { raising family food) }\end{array}$ \\
\hline Kenya & $\begin{array}{l}\text { Inside house (food preparation, } \\
\text { cooking, cleaning, and washing } \\
\text { household clothes) } \\
\text { Outside house (going to market, } \\
\text { sending messages, fetching water, and } \\
\text { washing clothes outside home) } \\
\text { Caring for children, sick, and elderly }\end{array}$ & $\begin{array}{l}\text { Employment outside } \\
\text { family (includes wage } \\
\text { work or looking for } \\
\text { work) }\end{array}$ & $\begin{array}{l}\text { Home construction, } \\
\text { repair, and } \\
\text { maintenance } \\
\text { Helping with } \\
\text { subsistence production, } \\
\text { family farm, or } \\
\text { business }\end{array}$ \\
\hline Nicaragua & $\begin{array}{l}\text { Cooking, washing dishes, doing } \\
\text { laundry, ironing, cleaning house } \\
\text { Repairing house, backyard } \\
\text { Collecting water, picking up firewood } \\
\text { Buying food, clothes, home articles } \\
\text { Caring for children (exclusive), } \\
\text { pregnancy (only for women), and sick }\end{array}$ & $\begin{array}{l}\text { Salaried or } \\
\text { remunerated job }\end{array}$ & Nonremunerated job \\
\hline Pakistan & $\begin{array}{l}\text { Inside house (dishwashing, cleaning, } \\
\text { cooking, mending, etc.) } \\
\text { Outside house (working in fields, } \\
\text { raising livestock, fetching water, etc.) } \\
\text { Caring for children, sick, and elderly }\end{array}$ & Paid work & $\begin{array}{l}\text { Unpaid work (other } \\
\text { than household chores) }\end{array}$ \\
\hline $\begin{array}{l}\text { South } \\
\text { Africa }\end{array}$ & $\begin{array}{l}\text { Cooking, cleaning, washing clothes, } \\
\text { preparing food } \\
\text { Fetching water and/or firewood/ } \\
\text { paraffin/dung } \\
\text { Home construction and maintenance, } \\
\text { working in yard } \\
\text { Caring for children, sick, and elderly } \\
\text { Shopping for household }\end{array}$ & $\begin{array}{l}\text { Paid work outside } \\
\text { family }\end{array}$ & $\begin{array}{l}\text { Helping with } \\
\text { subsistence production, } \\
\text { family farm, or } \\
\text { business }\end{array}$ \\
\hline
\end{tabular}


Table 3 Mean hours of total work time and leisure, 15-19-year-olds, by residence and school status, Nicaragua and South Africa

\begin{tabular}{|c|c|c|c|c|c|c|c|c|}
\hline \multirow[b]{3}{*}{$\begin{array}{l}\text { Residence/ } \\
\text { school status }\end{array}$} & \multicolumn{4}{|c|}{ NICARAGUA } & \multicolumn{4}{|c|}{ SOUTH AFRICA } \\
\hline & \multicolumn{2}{|c|}{ Male } & \multicolumn{2}{|c|}{ Female } & \multicolumn{2}{|c|}{ Male } & \multicolumn{2}{|c|}{ Female } \\
\hline & $\begin{array}{c}\text { School } \\
\text { day }\end{array}$ & $\begin{array}{l}\text { Any } \\
\text { day }\end{array}$ & $\begin{array}{c}\begin{array}{c}\text { School } \\
\text { day }\end{array} \\
\end{array}$ & $\begin{array}{l}\text { Any } \\
\text { day }\end{array}$ & $\begin{array}{c}\text { School } \\
\text { day }\end{array}$ & $\begin{array}{l}\text { Any } \\
\text { day }\end{array}$ & $\begin{array}{c}\begin{array}{c}\text { School } \\
\text { day }\end{array} \\
\end{array}$ & $\begin{array}{l}\text { Any } \\
\text { day }\end{array}$ \\
\hline \multicolumn{9}{|l|}{ Total work } \\
\hline Nonstudent & 7.2 & 7.0 & 8.3 & 8.1 & 4.6 & 4.0 & 5.6 & 5.6 \\
\hline Student & 1.8 & 2.3 & 3.2 & 3.6 & 1.1 & 1.4 & 2.2 & 2.5 \\
\hline Difference & 5.4 & 4.7 & 5.1 & 4.5 & 3.5 & 2.6 & 3.4 & 3.1 \\
\hline \multicolumn{9}{|l|}{ Rural } \\
\hline Nonstudent & 8.5 & 8.3 & 7.4 & 7.6 & 3.9 & 4.3 & 5.7 & 5.4 \\
\hline Student & 2.5 & 3.6 & 2.6 & 3.8 & 2.0 & 2.6 & 3.4 & 4.0 \\
\hline Difference & 6.0 & 4.7 & 4.8 & 3.8 & 1.9 & 1.7 & 2.3 & 1.4 \\
\hline \multicolumn{9}{|l|}{ Leisure } \\
\hline \multicolumn{9}{|l|}{ Urban } \\
\hline Nonstudent & 6.0 & 6.2 & 4.8 & 4.9 & 7.0 & 7.6 & 5.0 & 5.0 \\
\hline Student & 4.3 & 6.0 & 3.2 & 5.1 & 5.4 & 6.4 & 3.5 & 4.5 \\
\hline Difference & 1.7 & 0.2 & 1.6 & -0.2 & 1.6 & 1.2 & 1.5 & 0.5 \\
\hline \multicolumn{9}{|l|}{ Rural } \\
\hline Nonstudent & 4.8 & 5.0 & 5.6 & 5.5 & 6.8 & 6.8 & 5.0 & 5.1 \\
\hline Student & 3.5 & 5.7 & 3.2 & 5.3 & 4.2 & 5.2 & 2.7 & 3.5 \\
\hline Difference & 1.3 & -0.7 & 2.4 & 0.2 & 2.6 & 1.6 & 2.3 & 1.6 \\
\hline
\end{tabular}


Table 4 Direction and significance in the association between total work time and school enrollment, by country and reference period, according to residence and sex

\begin{tabular}{lccccccc}
\hline Country/ & \multicolumn{3}{c}{ Urban } & & \multicolumn{3}{c}{ Rural } \\
\cline { 2 - 3 } \cline { 7 - 8 } reference period & Male & Female & {$\left[\mathbf{F}^{<}>\mathbf{M}\right]^{\mathbf{a}}$} & & Male & Female & {$\left[\mathbf{F}^{<}>\mathbf{M}\right]^{\mathbf{a}}$} \\
\hline Guatemala (any day) & $-* * *$ & $-* * *$ & $<$ & & $-* * *$ & $-* * *$ & $<$ \\
India (school day) & $-* * *$ & $-* * *$ & $<* * *$ & & na & na & na \\
Kenya (school day) & na & na & na & & $-* * *$ & $-* * *$ & $<$ \\
Nicaragua & & & & & & & \\
$\quad$ School day & $-* * *$ & $-* * *$ & $<$ & & $-* * *$ & $-* * *$ & $<*$ \\
$\quad$ Any day & $-* * *$ & $-* * *$ & $<*$ & & $-* * *$ & $-* * *$ & $<* *$ \\
Pakistan (school day) & $-* * *$ & $-* * *$ & $<* * *$ & & $-* * *$ & $-* * *$ & $<$ \\
South Africa & & & & & & \\
$\quad$ School day & $-* * *$ & $-* *$ & $<$ & & $-* * *$ & $-*$ & $<*$ \\
$\quad$ Any day & $-* * *$ & $-* * *$ & $>$ & & $-*$ & - & $<$ \\
\hline
\end{tabular}

Note: Based on the Tobit regression, the dependent variable is total work time (daily hours); the independent variables are age, enrollment status, interactions of age and enrollment status, and marital status.

* Significant at $\mathrm{p} \leq 0.05 ;{ }^{* *} \mathrm{p} \leq 0.01 ; * * \mathrm{p} \leq 0.001$. na $=$ Not available.

${ }^{a}$ The relationship between females and males is based on the relative size of their coefficients, whereas the significance is based on the interaction of sex and enrollment status.

Table 5 Direction and significance in the association between noneconomic household work and school enrollment, by country and reference period, according to residence and sex

\begin{tabular}{|c|c|c|c|c|c|c|}
\hline \multirow{2}{*}{$\begin{array}{l}\text { Country/ } \\
\text { reference period }\end{array}$} & \multicolumn{3}{|c|}{ Urban } & \multicolumn{3}{|c|}{ Rural } \\
\hline & Male & Female & {$\left[\mathbf{F}^{<}>\mathbf{M}\right]^{\mathbf{a}}$} & Male & Female & {$\left[\mathbf{F}^{<}>\mathbf{M}\right]^{\mathbf{a}}$} \\
\hline Guatemala (any day) & + & $-* *$ & $>* * *$ & + & - & $>* *$ \\
\hline India (school day) & $-* * *$ & - *** & $>* * *$ & na & na & na \\
\hline Kenya (school day) & na & na & na & - & $-* * *$ & $>* * *$ \\
\hline \multicolumn{7}{|l|}{ Nicaragua } \\
\hline School day & - & $-* * *$ & $>* *$ & $-*$ & _*** & $>* *$ \\
\hline Any day & - & $-* * *$ & $>^{*}$ & - & - *** & $>* * *$ \\
\hline Pakistan (school day) & + & -*** & $>* * *$ & -*** & -*** & $>* * *$ \\
\hline \multicolumn{7}{|l|}{ South Africa } \\
\hline School day & $-* * *$ & $-* * *$ & $>$ & $-* * *$ & $-* *$ & $<$ \\
\hline Any day & _*** & $-* * *$ & $>* * *$ & $-* * *$ & - & $<$ \\
\hline
\end{tabular}

Note: Based on the Tobit regression, the dependent variable is the total time spent on noneconomic household work (daily hours); the independent variables are age, enrollment status, interactions of age and enrollment status, and marital status.

* Significant at $\mathrm{p} \leq 0.05 ; * * \mathrm{p} \leq 0.01 ; * * * \mathrm{p} \leq 0.001$.

na $=$ Not available.

a The relationship between females and males is based on the relative size of their coefficients, whereas the significance is based on the interaction of sex and enrollment status. 
Table 6 Direction and significance in the association between labor market work and school enrollment, by country and reference period, according to residence and sex

\begin{tabular}{|c|c|c|c|c|c|c|}
\hline \multirow{2}{*}{$\begin{array}{l}\text { Country/ } \\
\text { reference period }\end{array}$} & \multicolumn{3}{|c|}{ Urban } & \multicolumn{3}{|c|}{ Rural } \\
\hline & Male & Female & {$\left[\mathbf{F}^{<}>\mathbf{M}\right]^{\mathrm{a}}$} & Male & Female & {$\left[\mathbf{F}^{<}>\mathbf{M}\right]^{\mathbf{a}}$} \\
\hline Guatemala (any day) & -*** & $-* * *$ & $<* * *$ & $-* * *$ & -*** & $>$ \\
\hline India (school day) & -*** & $-* * *$ & $<* * *$ & na & na & na \\
\hline Kenya (school day) & na & na & na & $-* * *$ & - & $<* *$ \\
\hline \multicolumn{7}{|l|}{ Nicaragua } \\
\hline School day & -*** & - & $<*$ & $-* *$ & - & $<$ \\
\hline Any day & -*** & - & $<$ & $-* * *$ & - & $<$ \\
\hline Pakistan (school day) & -*** & _*** & $<* * *$ & $-* * *$ & $-* * *$ & $<$ \\
\hline \multicolumn{7}{|l|}{ South Africa } \\
\hline School day & na & na & na & na & na & na \\
\hline Any day & na & na & na & na & na & na \\
\hline
\end{tabular}

Note: Based on the Tobit regression, the dependent variable is total time spent on labor market work (daily hours); the independent variables are age, enrollment status, interactions of age and enrollment status, and marital status.

* Significant at $\mathrm{p} \leq 0.05 ;{ }^{*} \mathrm{p} \leq 0.01 ; * * * \mathrm{p} \leq 0.001$.

na $=$ Not available.

${ }^{a}$ The relationship between females and males is based on the relative size of their coefficients, whereas the significance is based on the interaction of sex and enrollment status.

Table 7 Direction and significance in the association between leisure time and school enrollment, by country and reference period, according to residence and sex

\begin{tabular}{|c|c|c|c|c|c|c|}
\hline \multirow{2}{*}{$\begin{array}{l}\text { Country/ } \\
\text { reference period }\end{array}$} & \multicolumn{3}{|c|}{ Urban } & \multicolumn{3}{|c|}{ Rural } \\
\hline & Male & Female & {$\left[\mathbf{F}^{<}>\mathbf{M}\right]^{\mathbf{a}}$} & Male & Female & {$\left[\mathbf{F}^{<}>\mathbf{M}\right]^{\mathrm{a}}$} \\
\hline Guatemala (any day) & + & $-* * *$ & $>^{\mathrm{b}}$ & $+*$ & $+* *$ & $>^{\mathrm{a}}$ \\
\hline India (school day) & $-* * *$ & -*** & $>* * *$ & na & na & na \\
\hline Kenya (school day) & na & na & na & - & $-^{*}$ & $>$ \\
\hline \multicolumn{7}{|l|}{ Nicaragua } \\
\hline School day & - & -*** & $>$ & - & -*** & $>^{*}$ \\
\hline Any day & + & - & $>$ & $+*$ & - & $>*$ \\
\hline Pakistan (school day) & -* & $-* * *$ & $>^{*}$ & - *** & $-^{*}$ & $<*$ \\
\hline \multicolumn{7}{|l|}{ South Africa } \\
\hline School day & - & - & $>$ & - & - & $>*$ \\
\hline Any day & + & - & $>$ & + & - & $>$ \\
\hline
\end{tabular}

Note: Based on the Tobit regression, the dependent variable is total time spent on leisure (daily hours); the independent variables are age, enrollment status, interactions of age and enrollment status, and marital status.

* Significant at $\mathrm{p} \leq 0.05 ; * * \mathrm{p} \leq 0.01 ; * * \mathrm{p} \leq 0.001$.

na $=$ Not available.

${ }^{a}$ The relationship between females and males is based on the relative size of their coefficients, whereas the significance is based on the interaction of sex and enrollment status. ${ }^{b}$ Leisure time increases more for girls. 
Figure 1 Percentage of 15-19-year-olds currently enrolled in school, by country, residence, and sex
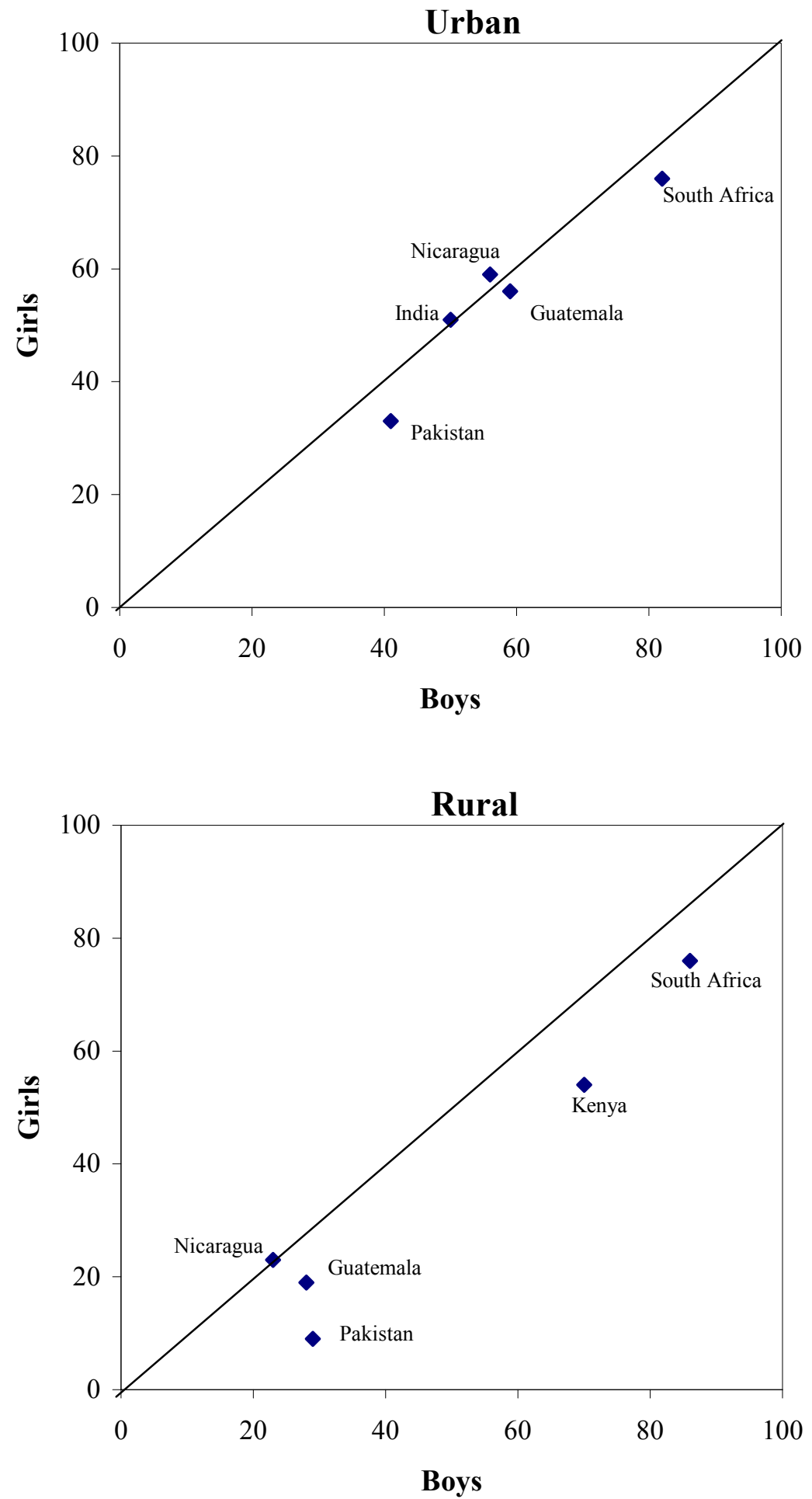

Note: No urban sample for Kenya; no rural sample for India. 
Figure 2 Total time 15-19-year-old students spent in school and studying on a school day, by country and sex

\section{Urban}

- Boys $\square$ Girls

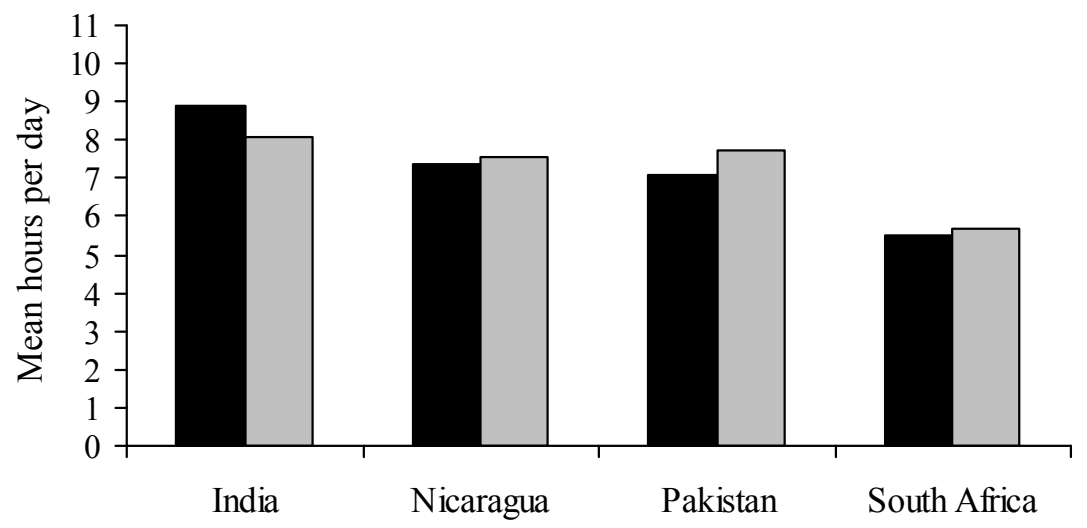

Rural

- Boys $\square$ Girls

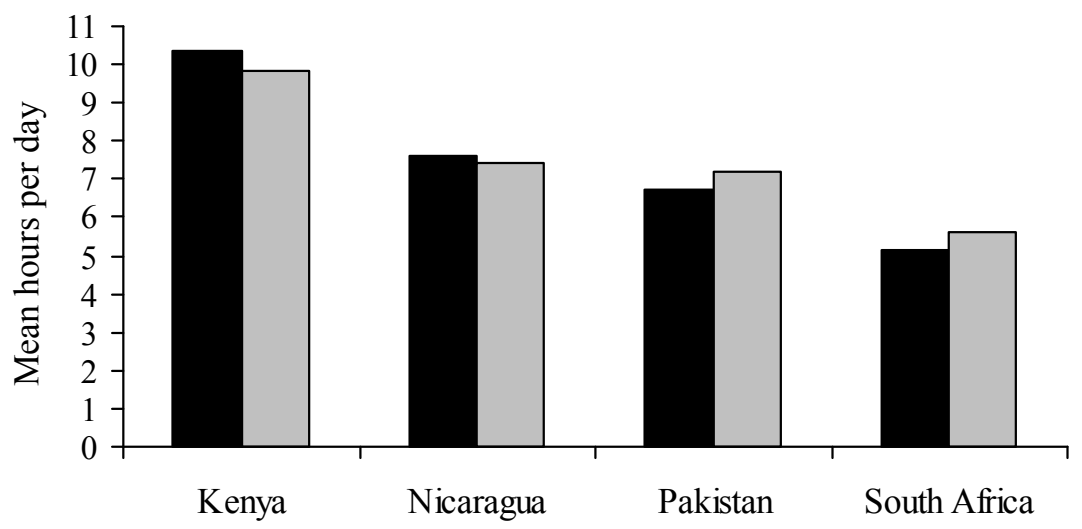


Figure 3 Total time 15-19-year-olds spent on work (labor market work and noneconomic household work combined) on a school day or any day, by country, residence, school status, and sex

Urban
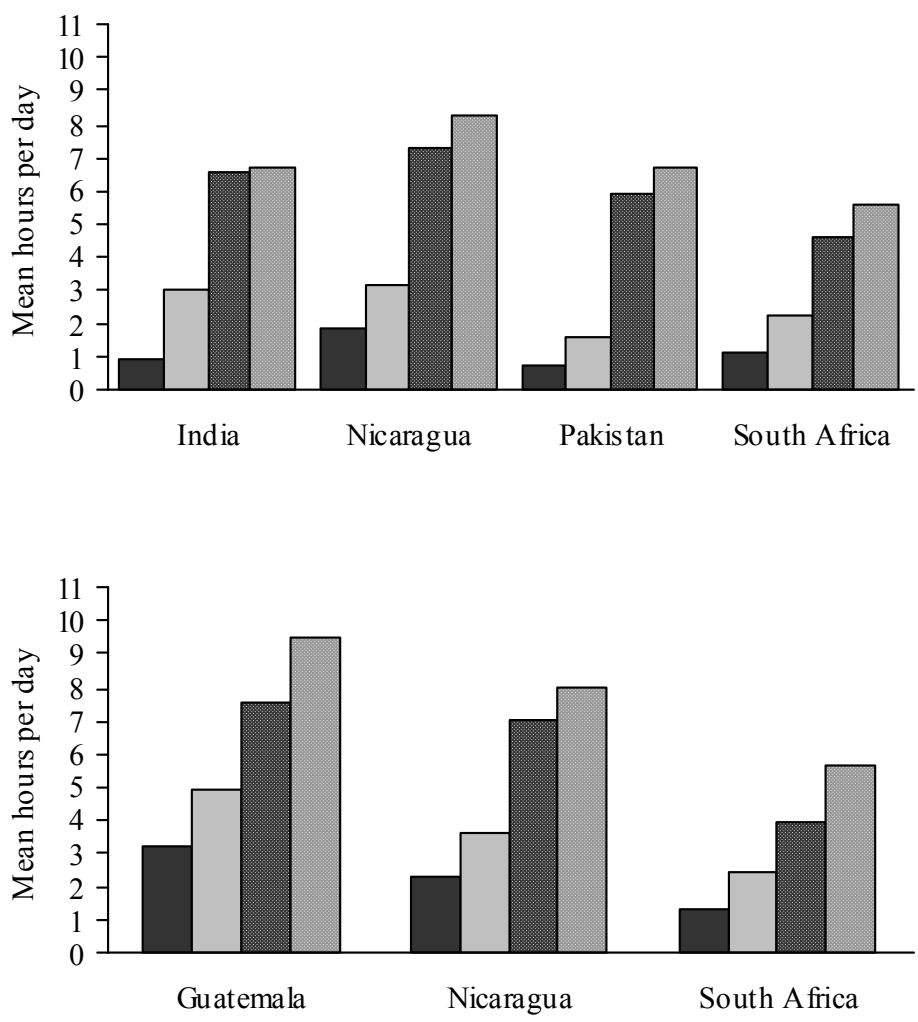

Male student

\section{School day}

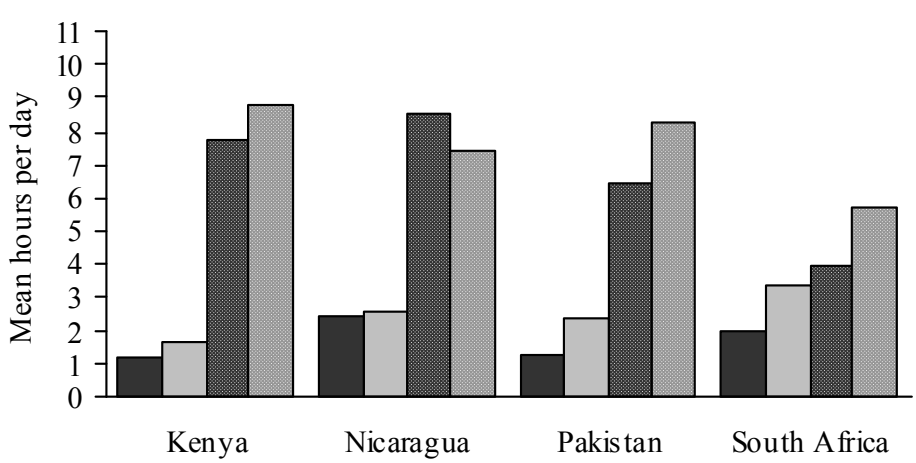

Any day

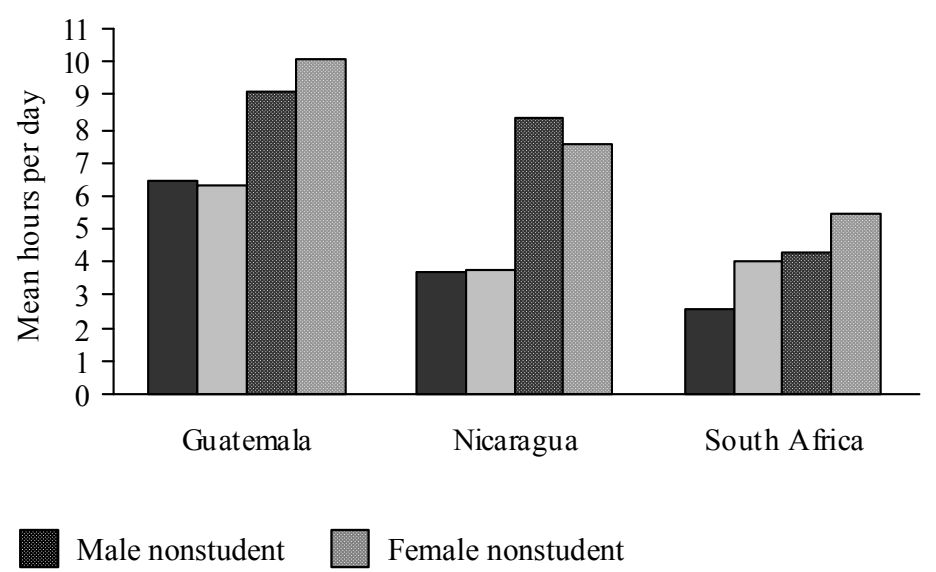


Figure 4 Total time 15-19-year-olds spent on noneconomic household work on a school day or any day, by country, residence, school status, and sex

\section{Urban}
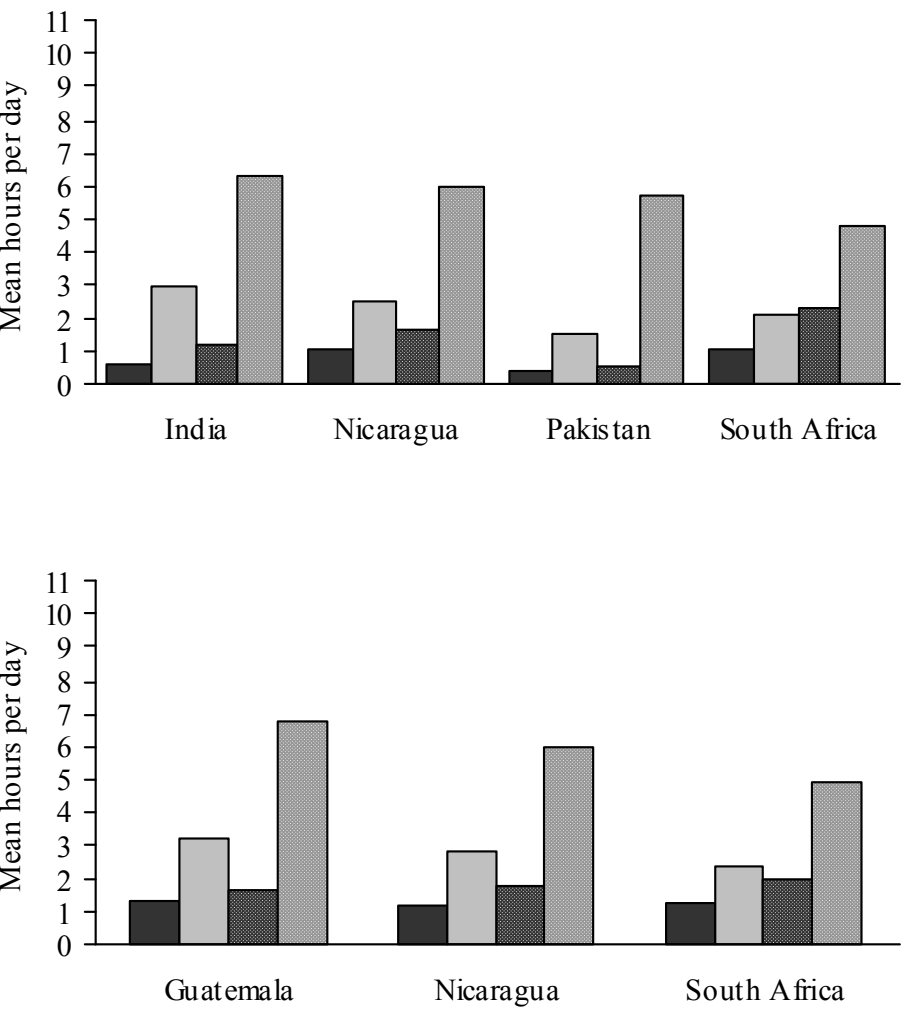

Male student

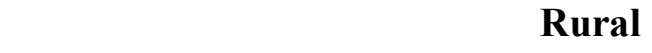

School day

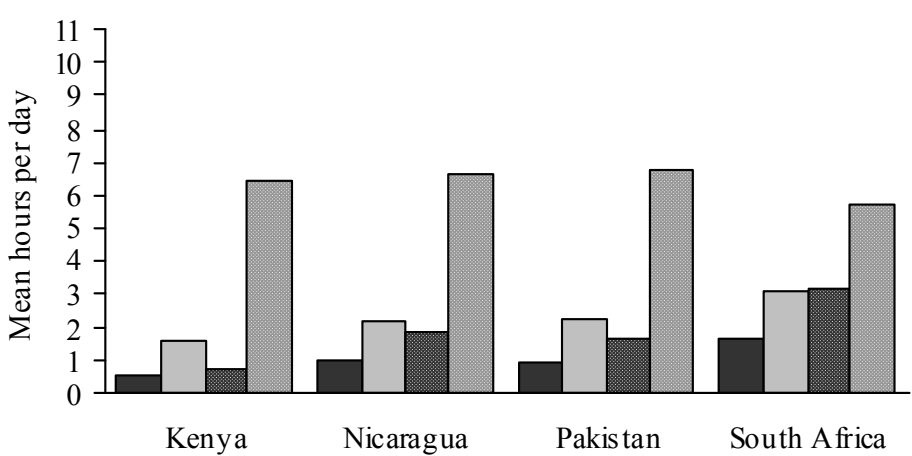

Any day

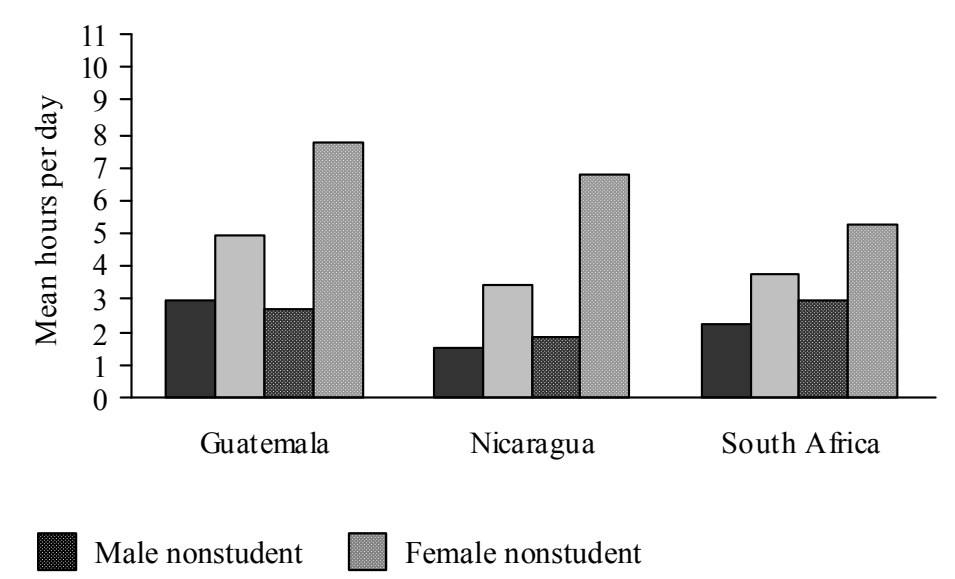


Figure 5 Total time 15-19-year-olds spent on labor market work on a school day or any day, by country, residence, school status, and sex
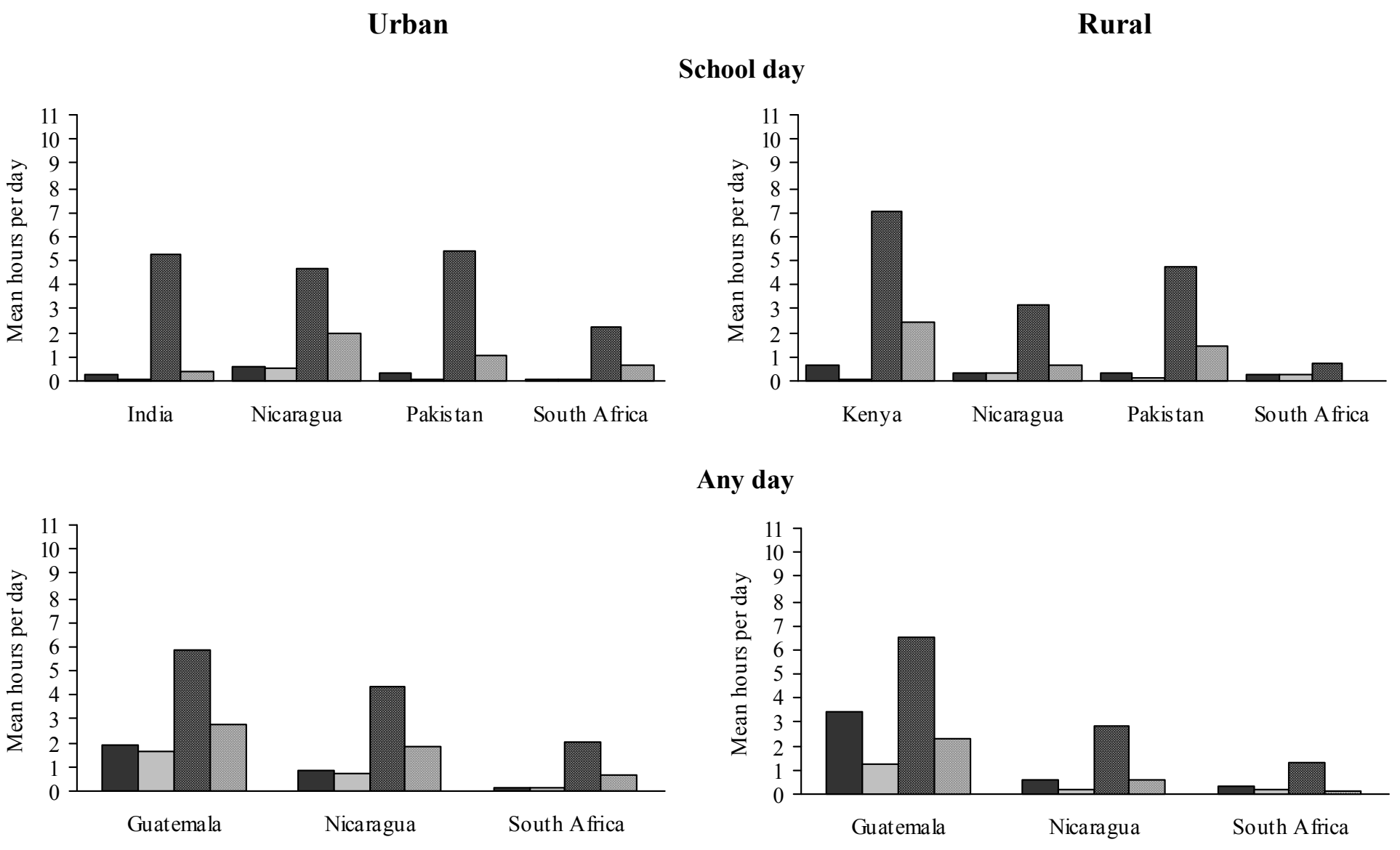

Any day

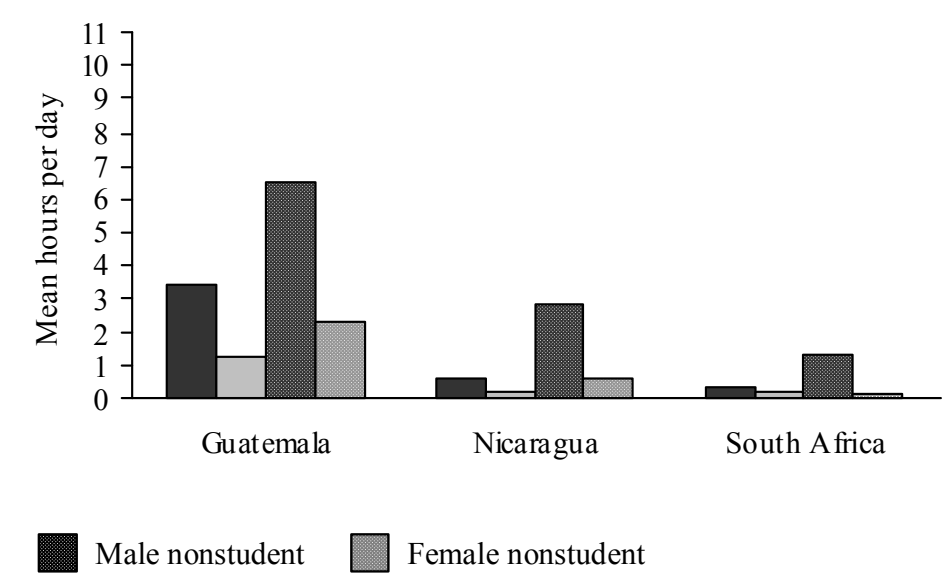


Figure 6 Total time 15-19-year-olds spent on leisure activities on a school day or any day, by country, residence, school status, and sex

\section{Urban}
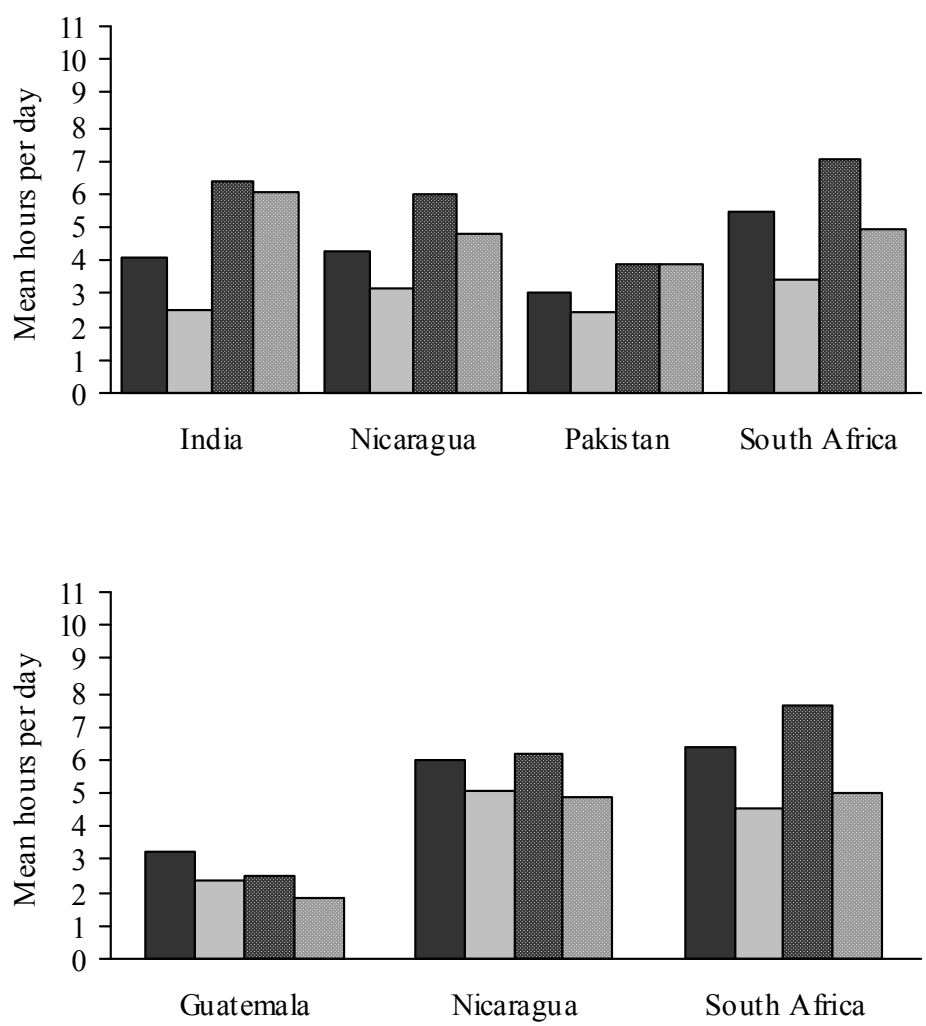

Rural

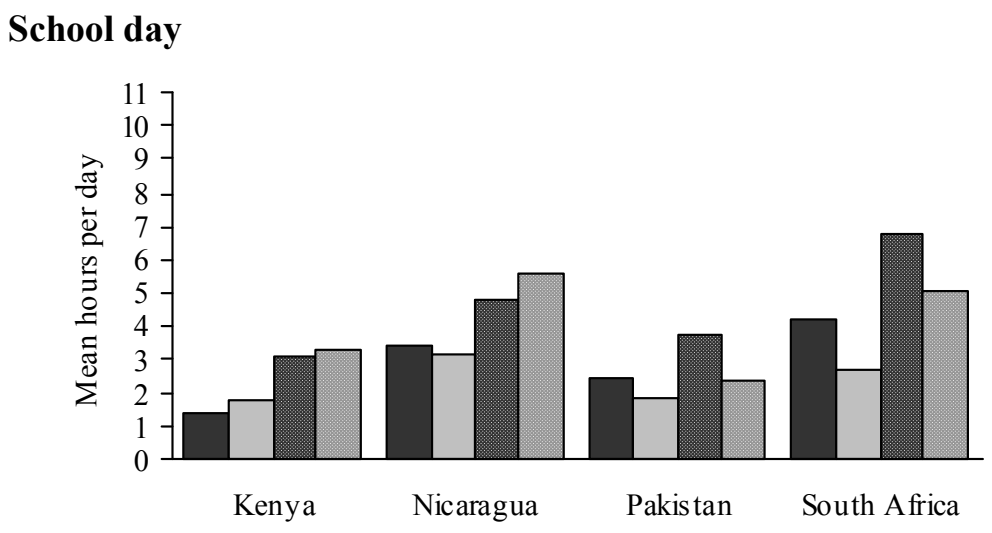

Any day

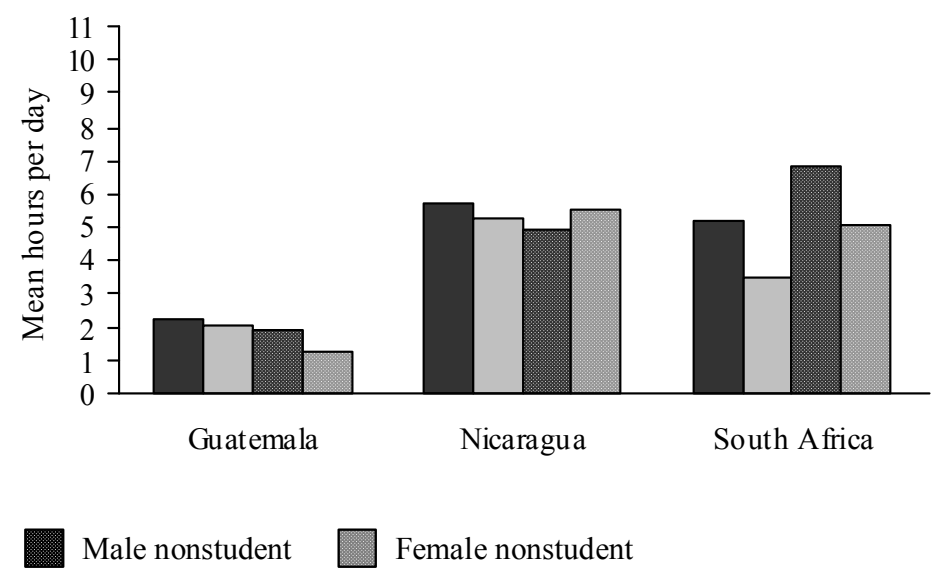




\section{REFERENCES}

Abler, David, José Rodríguez, and Héctor Robles. 1998. "The allocation of children's time in Mexico and Peru," prepared for presentation at the Comparative and International Education Society's CIES98 Conference, Buffalo, New York, 21 March.

Arends-Kuenning, Mary and Sajeda Amin. 2003. "The effects of schooling incentive programs on children's time allocation in Bangladesh," unpublished.

Cain, Mead T. 1977. "The economic activities of children in a village in Bangladesh," Population and Development Review 3(3): 201-227.

Canagarajah, Sudharshan and Harold Coulombe. 1998. Child Labor and Schooling in Ghana. Washington, DC: World Bank.

Chobokoane, Ntebaleng and Debbie Budlender. 2002. "A day in the life of a South African teenager," Statistics South Africa Occasional Paper.

Durrant, Valerie L. 2000. "Adolescent girls and boys in Pakistan: Opportunities and constraints in the transition to adulthood," Population Council Research Report No. 12.

- 2003. Personal communication.

Ersado, Lire. 2002. "Child labor and school decisions in urban and rural areas: Cross-country evidence." Washington, DC: International Food Policy Research Institute, Food Consumption Nutrition Division, Discussion Paper 145.

Evenson, R.E., B.M. Popkin, and E.K. Quizon. 1980. "Nutrition, work, and demographic behaviour in rural Philippine households," in H.P. Binswanger, R.E. Evenson, C.A. Florencio, and B.N.F. White (eds.), Rural Household Studies in Asia. Singapore: Singapore University Press.

Huebler, Friedrich and E. Loaiza. 2002. "Child labor and school attendance in sub-Saharan Africa: Empirical evidence from UNICEF's multiple indicator cluster surveys (MICS)," Strategic Information Section, Division of Policy and Planning, UNICEF, unpublished.

Ilahi, Nadeem. 2001. "Children's work and schooling: Does gender matter? Evidence from the Peru LSMS panel data," paper prepared for The Policy Research Report on Gender. Washington, DC: World Bank.

Jain, Devaki. 1996. "Valuing work: Time as a measure," Economic and Political Weekly 31(43): $46-57$. 
Kramer, Karen L. 2002. "Variation in juvenile dependencies: Helping behavior among Mayan children," Human Nature 13(2): 299-325.

Larson, Reed W. and Susan Verma. 1999. "How children and adolescents spend time across the world: Work, play, and developmental opportunities," Psychological Bulletin 125(6): 701-736.

Levison, Deborah. 1993. Child Work and Schooling in Brazil's Cities: Lessons from Survey Data. Monograph for International Labour Office, Geneva, unpublished.

Levison, Deborah and Karine S. Moe. 1998. "Household work as a deterrent to schooling: An analysis of adolescent girls in Peru," Journal of Developing Areas 32(3): 339-356.

Levison, Deborah, Karine S. Moe, and Felicia Marie Knaul. 2001. "Youth education and work in Mexico," World Development 29(1): 167-188.

Lloyd, Cynthia B. and Monica J. Grant. 2004. "Growing up in contemporary Pakistan: The separate experiences of males and females," Policy Research Division Working Paper no. 188. New York: Population Council.

Mason, Andrew W. and Shahidur R. Khandker. 1998. "Children's work, opportunity cost and schooling in Tanzania," in S. Canagarajah and H. Skyt Nielsen (eds.), Child Labor and Schooling in Africa: A Case Study of Ghana, Tanzania, Côte d'Tvoire and Zambia. Washington, DC: Social Protection Network, World Bank, unpublished.

Mensch, Barbara S., Judith Bruce, and Margaret E. Greene. 1998. The Uncharted Passage: Girls'Adolescence in the Developing World. New York: Population Council.

Nag, Moni, N. F. White, and R. Creighton Peet. 1978. "An anthropological approach to the study of the economic value of children in Java and Nepal," Current Anthropology 19 (2): 293-306.

National Research Council and Institute of Medicine, Panel on Transitions to Adulthood in Developing Countries. 2005a. Cynthia B. Lloyd (ed.), Growing Up Global: The Changing Transitions to Adulthood in Developing Countries. Washington, DC: National Academies Press.

-2005b. Cynthia B. Lloyd, Jere R. Behrman, Nelly P. Stromquist, and Barney Cohen (eds.), The Changing Transitions to Adulthood in Developing Countries: Selected Studies. Washington, DC: National Academies Press.

Psacharopoulos, George. 1997. "Child labor versus educational attainment: Some evidence from Latin America," Journal of Population Economics 10(4): 377-386. 
Ravallion, Martin and Quentin Wodon. 2000. "Does child labor displace schooling? Evidence on behavioral responses to an enrollment study," The Economic Journal 110(462): 158-175.

Rodgers, Gerry and Guy Standing. 1981. "The economic roles of children: Issues for analysis," in Gerry Rodgers and Guy Standing (eds.), Child Work, Poverty and Underdevelopment. Geneva: International Labour Office.

Skoufias, Emmanuel and Susan W. Parker. 2002. "Labor market shocks and their impacts on work and schooling: Evidence from urban Mexico." Washington, DC: International Food Policy Research Institute, Food Consumption and Nutrition Division, Discussion Paper 129.

- Forthcoming. "The impact of PROGRESA on child labor and schooling," in P. Orazem, G. Sedlacek, and Z. Tzannatos (eds.), Child Labor in Latin America. Washington, DC: World Bank and Inter-American Development Bank.

Torun, B., P.S.W. Davies, M.B.E. Livingstone, M. Paolisso, R. Sackett, and G.B. Spurr. 1994. "Energy requirements and dietary energy recommendations for children and adolescents 1 to 18 years old," in Energy and Protein Requirements: Proceedings of an International Dietary Energy Consultative Group Held in London, October 31 - November 4, 1994.

Uganda Bureau of Statistics and ORC Macro. 2002. Uganda DHS EdData Survey 2001: Education Data for Decision-making. Entebbe, Uganda and Calverton, MD: Uganda Bureau of Statistics and ORC Macro.

United Nations Millennium Project. 2004. From Promises to Action: Recommendations for Gender Equality and Empowerment of Women. Task Force 3 Interim Report on Gender Equality.<http://www.unmillenniumproject.org/documents/tf3genderinterim.pdf.>

Accessed 18 March 2004.

World Bank. 2001. Engendering Development Through Gender Equality in Rights, Resources, and Voice. A World Bank Policy Research Report. Washington, DC and Oxford: World Bank and Oxford University Press. 


\section{POLICY DIVISION WORKING PAPERS}

If still in print, single copies of up to three working papers from 1989 through 2003 are available free of charge.

Beginning with the 2004 issues, the working papers will no longer be available in print format. Instead they will be distributed electronically. As each new paper is completed subscribers will be notified by e-mail and a link to the paper will be provided.

To subscribe to the Policy Research Division working paper e-mail notification list, or to obtain back issues from 1989 to 2003, please send your request to prdwp@popcouncil.org.

PDFs of recent issues are available at www.popcouncil.org/publications/wp/prd/rdwplist.html

2004

193 Amanda Ritchie, Cynthia B. Lloyd, and Monica Grant. "Gender differences in time use among adolescents in developing countries: Implications of rising school enrollment rates."

192 John Bongaarts. "Long-range trends in adult mortality: Models and projection methods."

191 John Koku Awoonor-Williams, Ellie S. Feinglass, Rachel Tobey, Maya N. Vaughan-Smith, Frank K. Nyonator, Tanya C. Jones, and James F. Phillips, "Bridging the gap between evidence-based innovation and national healthsector reform in Ghana."

190 Kelly Hallman, "Socioeconomic disadvantage and unsafe sexual behaviors among young women and men in South Africa."

189 Toshiko Kaneda, Zachary Zimmer, and Zhe Tang, "Differentials in life expectancy and active life expectancy by socioeconomic status among older adults in Beijing."
188 Cynthia B. Lloyd and Monica J. Grant, "Growing up in Pakistan: The separate experiences of males and females."

187 Zachary Zimmer, Xianghua Fang, Toshiko Kaneda, Zhe Tang, and Julia Kwong. "Trends and transitions in children's coresidence with older adults in Beijing municipality."

186 Sajeda Amin and Alaka M. Basu. "Popular perceptions of emerging influences on mortality and longevity in Bangladesh and West Bengal."

185 John Bongaarts. "Population aging and the rising cost of public pensions."

184 Mark R. Montgomery and Paul C. Hewett. "Urban poverty and health in developing countries: Household and neighborhood effects.

\footnotetext{
* No longer available as a printed publication. Download electronic file from Web site only.
} 
2003

183 Agnes R. Quisumbing and Kelly Hallman. "Marriage in transition: Evidence on age, education, and assets from six developing countries."

182 Paul C. Hewett, Barbara S. Mensch, and Annabel S. Erulkar, "Consistency in the reporting of sexual behavior among adolescent girls in Kenya: A comparison of interviewing methods."

181 Zachary Zimmer, Linda G. Martin, and Hui-Sheng Lin, "Determinants of old-age mortality in Taiwan."

180 Frank K. Nyonator, J. Koku Awoonor-Williams, James F. Phillips, Tanya C. Jones, and Robert A. Miller, "The Ghana Community-based Health Planning and Services Initiative: Fostering evidence-based organizational change and development in a resourceconstrained setting."

179 John Bongaarts and Griffith Feeney, "Estimating mean lifetime."

178 Elizabeth F. Jackson, Patricia Akweongo, Evelyn Sakeah, Abraham Hodgson, Rofina Asuru, and James F. Phillips, "Women's denial of having experienced female genital cutting in northern Ghana: Explanatory factors and consequences for analysis of survey data."
177 John Bongaarts, "Completing the fertility transition in the developing world: The role of educational differences and fertility preferences."

176 Cynthia B. Lloyd and Paul C. Hewett, "Primary schooling in sub-Saharan Africa: Recent trends and current challenges."

175 James F. Phillips, Tanya C. Jones, Frank K. Nyonator, and Shruti Ravikumar, "Evidence-based development of health and family planning programs in Bangladesh and Ghana."

174 Geoffrey McNicoll, "Population and development: An introductory view."

173 Paul Demeny, "Population policy: A concise summary."

172 Zachary Zimmer, Napaporn Chayovan, Hui-Sheng Lin, and Josefina Natividad, "How indicators of socioeconomic status relate to physical functioning of older adults in three Asian societies."

171 Sajeda Amin and Nagah H. AlBassusi, "Wage work and marriage: Perspectives of Egyptian working women."

170 Ravai Marindo, Steve Pearson, and John B. Casterline, "Condom use and abstinence among unmarried young people in Zimbabwe: Which strategy, whose agenda?"

\footnotetext{
* No longer available as a printed publication. Download electronic file from Web site only.
} 
169

Zachary Zimmer and Julia

Dayton, "The living arrangements

of older adults in sub-Saharan

Africa in a time of HIV/AIDS."

168 Paul C. Hewett, Annabel S. Erulkar, and Barbara S. Mensch, "The feasibility of computerassisted survey interviewing in Africa: Experience from two rural districts in Kenya."

2002

167* Dominic K. Agyeman and John B. Casterline, "Social organization and reproductive behavior in southern Ghana."

166* Carol E. Kaufman and Stavros E. Stavrou, “'Bus fare, please': The economics of sex and gifts among adolescents in urban South Africa."

165 Kelly Hallman, Agnes R. Quisumbing, Marie Ruel, and Bénédicte de la Brière, "Childcare, mothers' work, and earnings: Findings from the urban slums of Guatemala City."

164 Cynthia B. Lloyd, Cem Mete, and Zeba A. Sathar, "The effect of gender differences in primary school access, type, and quality on the decision to enroll in rural Pakistan."

163 Barbara S. Mensch, Wesley H. Clark, and Dang Nguyen Anh, "Premarital sex in Vietnam: Is the current concern with adolescent reproductive health warranted?"
162 Naomi Rutenberg, Carol E. Kaufman, Kate Macintyre, Lisanne Brown, and Ali Karim, "Pregnant or positive: Adolescent childbearing and HIV risk in South Africa."

161 John Bongaarts, "The end of the fertility transition in the developing world."

160* Julia Dayton and Martha Ainsworth, "The elderly and AIDS: Coping strategies and health consequences in rural Tanzania."

159 Carol E. Kaufman, Shelley Clark, Ntsiki Manzini, and Julian May, "How community structures of time and opportunity shape adolescent sexual behavior in South Africa."

158 Geoffrey McNicoll, "Demographic factors in East Asian regional integration."

157 Zachary Zimmer and Sovan Kiry Kim, "Living arrangements and socio-demographic conditions of older adults in Cambodia."

156 John Bongaarts and Griffith Feeney, "How long do we live?"

155 Zachary Zimmer, Linda G. Martin, and Ming-Cheng Chang, "Changes in functional limitations and survival among the elderly in Taiwan: 1993, 1996, and 1999."

\footnotetext{
* No longer available as a printed publication. Download electronic file from Web site only.
} 